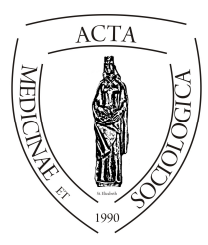

Acta Medicinae et

Sociologica (2019)

Vol. 10. No. 28.

DEBRECEN

FACULTY OF

HEALTH

doi:

\title{
Oktatók és facilitátorok különböző oktatási terekben
}

\author{
Kristóf Zsolt ${ }^{1}$ - Varga Anita ${ }^{2}$ \\ ${ }^{1}$ adjunktus, Debreceni Egyetem, Egészségügyi Kar, Egészségtudományi Intézet, Egészségügyi Informatikai nem \\ önálló Tanszék. 4400 Nyíregyháza, Sóstói u. 2-4. \\ ${ }^{2}$ egészségügyi szervező, Debreceni Egyetem Egészségügyi Kar. 4400 Nyíregyháza, Sóstói u. 2-4.
}

\section{INFO}

\section{ABSTRACT}

Teachers and facilitators in different teaching spaces Nowadays the information society can not imagine its everyday life without the use of the Internet. Keelan and her colleagues determined the benefits that virtual worlds can impact to traditional territories. Virtual spaces can abolish physical-geographic boundaries in cases where research is far apart from the group of people to be examined (Keelan et al. 2015). Whether we are planning to implement the education process in real space or virtual space, explanation and assistance in many cases may be indispensable. Gamage and his research associates differentiated the subjects of their research as to how much they had experienced in the use of virtual spaces. Both groups agreed that the use of platforms was an advantage in learning but they differed in their opinion of the likelihood of emotional connection between teacher and student in the virtual world (Gamage et al. 2011). The activities of teaching assistants can be useful not only in the real learning environment, but also in the virtual learning environment. The facilitator is a person who can work efficiently with both the instructor and the students. The facilitator contributes to the smoothness and effectiveness of teaching processes (Schwarz et al. 2011). In our article, we present and define the preceding, participatory, follow-up and continuous facilitator roles we have outlined. From the facilitator's point of view and from the traditional learning environment we get to the exact parameters of the role that is necessarily emerging in the learning environments of virtual spaces.

Kulcsszavak

facilitátor, oktatási tér, Second Life
Absztrakt: Az információs társadalom ma már nem tudja elképzelni mindennapjait az internet használata nélkül. Keelan és munkatársai meghatározták azokat az előnyöket, amelyeket a hagyományos területekhez képest biztosít a virtuális világok használata. A virtuális terek eltörölhetik a 


\begin{abstract}
fizikai-földrajzi határokat azokban az esetekben, ahol meszsze esik egymástól a kutatás a fizikai világban és a vizsgálni kívánt embercsoport (Keelan et al. 2015). Akár a valós térben, akár a virtuális térben tervezzük megvalósítani az oktatási folyamatot, a magyarázat és a segítségnyújtás sok esetben elengedhetetlen lehet. Gamage és kutatótársai aszerint különböztették meg kutatásuk alanyait, hogy azok mennyire voltak tapasztaltak a virtuális terek használatában. Mindkét csoport egyetértett abban, hogy a platformok használata előnyt jelent a tanulás során, abban azonban eltért a véleményük, hogy mennyire valószínủ az érzelmi kapcsolat a tanár és diák között ebben a sok felhasználót foglalkoztató világban (Gamage et al. 2011). Nemcsak a valós térben, hanem a virtuális térben történő oktatási folyamatokban is hasznos lehet az oktatássegítő személyek tevékenysége. A facilitátor olyan személy, aki hatékonyan együtt tud dolgozni az oktatóval és hallgatókkal egyaránt. Hozzájárul ahhoz, hogy a tanítási folyamatok gördülékenyen és a lehető leghatásosabban menjenek végbe a figyelem folyamatos fenntartása mellett (Schwarz et al. 2011). Cikkünkben bemutatjuk és definiáljuk az általunk körvonalazott megelőző, résztvevő, utólagos és folyamatos facilitátori szerepeket. A facilitátor szemszögéből, a valós tér hagyományos oktatási környezetéböl kiindulva eljutunk a virtuális terek tanulókörnyezeteiben szükségképpen megjelenő szerepkör pontos paramétereihez.
\end{abstract}

\title{
Bevezetés
}

A világ rohamosan fejlődik az élet minden területén. Amit néhány évvel ezelőtt még lehetetlennek hittünk, ma már mindennapos tevékenység. Mindenki másképp éli meg a körülötte végbemenő eseményeket, vannak, akik örülnek és vannak, akik bosszankodnak a minket behálózó modernizáció miatt. Az innováció az oktatásban is megfigyelhető, a jelenléti oktatás kiegészült különböző oktatást segítő módszerekkel, melyek többségére a hallgatóság nyitott.

Az információs társadalom ma már nem tudja elképzelni mindennapjait az internet használata nélkül. Az okos készülékek virágkorukat élik, egyre nagyobb igény van a gyártásukra. Kiemelt figyelmet fektetnek a készítők a kompatibilitásra, amely lehetővé teszi, hogy különböző eszközöket összekapcsoljunk, még kényelmesebbé téve ezzel azok használatát. Az oktatásban sincs ez másképp. Szinte minden könyv elérhető elektronikus formában is, így akár több száz könyvet magunkkal vihetünk egy adathordozó segítségével. Az e-learning és Moodle felületek bevezetésének köszönhetően már nemcsak kézzel írva, papír alapon adhat képet tudásáról a tanuló, hanem a számítógép elött ülve is. Ennek egyik legvitatottabb jellemzője, hogy a hallgatónak nem szükséges egyazon helyen tartózkodni az oktatóval.

Lewin és kollégái 1939-ben a tanári vezetés három különböző megközelítését körvonalazták. Meglátásuk szerint létezik tekintélyelvü, demokratikus és ráhagyó 
(laissez faire) oktatói magatartás (Lewin et al. 1939). Horváth 2004-ben ennek alapján a következőképpen foglalta össze a három csoport jellemzőit.

A tekintélyelvü oktatói vezetés alkalmazása során minden szükséges elvégezni valóról maga a folyamat vezetője dönt. A folyamatban részt vevő tanulók nem feltétlenül vannak tisztában az adott oktatás elsődleges irányával, a végcélhoz vezető út egyes lépéseit a vezető határozza meg. A tanulók feladatait és munkatársait szintén a vezető alakítja ki. Elképzelhető, hogy az értékelés során a vezető - mind a bírálat, mind a dicséret során - szubjektív, kevéssé barátságos, személytelen módon fejti ki véleményét.

A demokratikus oktatási folyamat során az egyes elvégzendő feladatokról maga a tanulócsoport dönthet úgy, hogy eközben a vezető jelenlétével, meglátásaival segíti, bátorítja a tanulókat. Másképpen megfogalmazva a csoport és az oktató együtt, közösen formálják a végcél beteljesítéséhez szükséges lépéseket. Előfordulhat, hogy a tanulóknak a továbbhaladáshoz technikai segítségre van szükségük. Ilyen esetekben a vezetőnek jellemzően több továbblépési lehetőséget kell felajánlania a tanulók számára, melyek hasonló hatékonyságúak. A feladatok felosztásáról és az egyes lehetséges munkatársak szerepéről is a tanulók dönthetnek. A vezető az értékelés során törekszik az objektivitásra és az életszerüségre.

A ráhagyó oktatói magatartás alkalmazása esetén a folyamatban felmerülő döntéseket nem a vezető, hanem a tanulók válaszolják meg. Ezzel együtt szükség van az oktatóra is, hiszen a végcél eléréséhez szükséges dolgokat biztosítania kell a tanulók felé. Az oktatónak tájékoztatni kell a tanulókat arról, hogy ha kérdés merül fel, akkor megválaszolja azt. A feladatok felosztása ugyanakkor teljes mértékben a tanulóktól függ. A folyamat végén a vezető nem értékel, legfeljebb megjegyzéseket füz az eredményekhez, ha erre külön megkérik (Horváth 2004).

Ahogy a fenti tanári magatartások a jelenléti oktatás világában jól körvonalazhatók, a digitális vagy virtuális megoldásokkal, valamint facilitátori munkával kiegészített oktatás területén érdemes más megközelítéseket is figyelembe venni.

\section{Szakirodalmi áttekintés}

Egyre nyilvánvalóbb, hogy a magyarázat a tanítási-tanulási folyamat során a legtöbb tanuló számára esszenciális fontossággal bír. Külföldön éppen ezért már online videókkal is kiegészítik a feltöltött tananyagot, hogy még egyszerübbé tegyék az érdeklődő hallgatók tanulási folyamatait. Nem gyakori, hogy az oktató a saját maga által készített videóval is támogassa az oktatási folyamatot. Ennek egyik oka az idő hiánya lehet, melyre megoldás lenne a facilitátorok használata. A facilitátor egy olyan személy, aki hatékonyan együtt tud dolgozni az oktatóval és hallgatósággal egyaránt. Semleges tud maradni az tanulási-tanítási folyamatban jelenlévő személyektől (Schwarz et al. 2011). Hozzájárul egy adott folyamat gördülékeny lebonyolításához. Ha az oktatóknak a másnapi órákra való felkészülés és a szakirodalom böngészése mellett nem kellene azzal is sok időt eltölteniük, hogy különböző, néha nem is nekik szóló üzenetekre válaszolnak, vagy számos dolgozatot javítanak, akkor valószínúleg könnyebben szánnák rá magukat ilyen videók elkészítésére. Az oktatók 
leterheltségén túl a tanulók motivációját is figyelembe kell vennünk. Kiváló lenne, ha az oktatási folyamatokba érkező tanulók mindegyike komoly motivációval rendelkezne. Tudjuk, hogy ez nincs így. És még ha bizonyos tanulók esetében meg is van a kellő motiváció, a mindennapi iskolai munka továbbra is unalmasnak vagy kevéssé fontosnak tünhet a diákok számára.

A tanári munka során három lényeges célunk lehet. Talán a legegyértelmübb cél az, hogy képesek legyünk tanulóinkat az osztály munkájába eredményesen bevonni. Célunk az is, hogy a diákok motivációját fejlesszük és emeljük, leginkább annak érdekében, hogy hosszabb távon, további tanulmányaikban könnyebben tudjanak önállóan is tanulni. A fentiek mellett pedig azt is szeretnénk, ha a tanulók a tanulás folyamatában mélyen és alaposan lennének képesek a gondolkodásra (Punjabi 2015).

A fentebb említett online videókon túl a virtuális térben megalkotott tanulást segítő alkalmazások, valamint közösségek is segíthetik a hatékony tanulás folyamatát. A virtuális közösségek számos módon megkönnyíthetik az egyes felhasználók avatárjainak virtuális életét. Mindenekelőtt érdemes tisztában lenni azzal, hogy a virtuális közösségek hosszú távú létezése annak köszönhető, hogy a tagok együttmüködnek. A fennmaradás a tagoktól erőfeszítéseket követel, továbbá belefektetett munkát és komoly elkötelezettséget is. A közösség és a környezet közötti kölcsönhatások sokszor passzív megfigyelöből aktív felhasználóvá alakítják a tagokat (Guitton 2012). A közösségek virtuális térben sem képeznek önálló univerzumot. Hiszen, azzal együtt, hogy a közösségek magukon belül viszonylag állandóak, meghatározottak maradnak, más közösségekkel a viszony jól meghatározható és le is írható matematikai módszerekkel (Cristofari \& Guitton 2014). Az egyes virtuális közösségek puszta létszámától jóval fontosabb az, hogy a tagok mennyire képesek az intenzív részvételre. A tagoknak olyan optimális csoporton belüli kommunikációt kell fenntartaniuk, ami az információ megosztásán és a hatékony tagok közötti interakciókon alapul (Guitton 2015). A virtuális közösségek megfelelő motivációt és elfoglaltságokat is adhatnak. Adott esetben, ezekben a virtuális közösségekben sorstársakra találhatnak a felhasználók, alacsony költségekkel és kockázatok nélkül próbálhatnak ki különböző cselekvéseket, miközben érzelmi támogatást is kaphatnak a többi felhasználótól (Sullivan et al. 2016).

Számos kutatás alapeleme a virtuális térben történő tanítás-tanulás. A terület megalkotása rengeteg időt és energiát elvesz az alkotó személy részéről, azonban olyan szituációk és helyzetek gyakorlására ad lehetőséget, melyre a valós életben nem lenne lehetőség.

Három tényezőt kell kiemelni minden esetben, ha a virtuális térben történő tanítást választja az oktató (Thackray et al. 2008). Ezen tulajdonságok köré csoportosítható a Second Life hatékony használata. A kérdéses kulcsjellemzők a következők:

- Difficult - Nehéz

A „nehéz” jellemzőre példa egy boncolási folyamat lefolytatása. Nem kivitelezhetetlen, de sokszor nem is könnyü az utánajárásokkal beszerezhető tetemek belső szerveinek bemutatása.

- Dangerous - Veszélyes

Egy virtuális világon belül, bármilyen fertőző betegség alaposan megvizsgálható, a valóságban fenn álló veszélyek nélkül. 
- Impossible - Lehetetlen

A valós térben, fizikai megtestesülésünkkel a véráramba történő bejutás, a véráram követése teljességgel lehetetlen, a virtuális térben azonban ez is megvalósítható.

A fenti esetekben jól nyomon követhető a valós pozitív hatása a virtuális oktatásnak. Negatívumként azonban megemlíthetö a válaszreakció. A páciens csak elöre beprogramozott válaszokat tud adni, ez a valós térben számtalan variációban előfordulhat. Az érzést nem tudja visszaadni a virtuális tér. A tapintás és a látás, tehát a saját érzékszervekkel tapasztalható dolgok hiánya pótolhatatlan.

A hagyományos módon szervezett oktatási folyamatoktól eltérve, a digitális világban a tartalmak átszervezésével vonzóbbá tehetjük a tanulást a diákok számára. Sokkal sokrétübben használhatók az anyagok, a tanuló egyéni sajátosságaihoz szabható a tananyag. Az átszervezéssel ugyanazon diáknak is többféleképpen mutatható meg ugyanaz az anyag, sőt, akár a tesztek is személyre szabhatók lehetnek (de Melo et al. 2014). Kiemelendő viszont, hogy a környezet sokkal bonyolultabb, komplexebb, mint a hagyományos, szövegorientált távoktatási formák esetén, az interakciók kevésbé szabályozhatók, ellenőrizhetők, és nyilvánosan történnek (de Noyelles \& Seo 2012).

A bonyolultság ellenére külföldi egyetemeken már elterjedt módszer, bizonyos kurzusok Second Life 3D-s virtuális világában történő meghirdetése. A medikus hallgatók számára jó néhány tárgy elérhető az SL-en belül. A leendő ortopédusok például erre a célra használhatják a deformitások, csigolyák és csontok tanulmányozásának megkönnyítésére azt a felületet, amelyet Kragujevac város egyeteme Szerbiában létrehozott számukra. A felnagyított emberi testet képző csontok olyan vizualizációs háromdimenziós modellek, melyek kimutatottan jó célt szolgálnak a megértés szolgálatában (Božović et al. 2014).

Az ápolási ismeretek átadásának céljából is készült már a virtuális térben olyan terület, ahol az életmentési technikák és csoportmunkában való együttmüködés fejlesztése volt a cél. Előadások és gyakorlati módszerek alkalmazásának elsajátítása is színesítette a kurzus repertoárját (Novotny \& Griffin 2011).

$\mathrm{Az}$ egészségügyi vonatkozásokon túl Eric B. Bauman a virtuális oktatás fejlődéséről írt, a játék alapú tanulás és szimuláció címü könyvében hosszasan kifejti, a virtuális tér adta előnyöket az oktatási folyamat szempontjából (Bauman 2012). Elsőként az elméleti tananyag elsajátításának fontosságát emeli ki, melyet kiegészít a virtuális tér nyújtotta gyakorlási lehetőséggel. Ezzel hozzájárul ahhoz, hogy minél szélesebb körben tapasztalatot szerezzenek a hallgatók. Megkönnyítve helyzetüket a későbbiekben, amikor a valóságban találkoznak majd a modellezett szituációkkal.

A virtuális térben nem csak tanítani, de kutatni is lehet elterjedtségének és gyakori oktatási célú használatának köszönhetően. Oktatási szempontból kiemelt szerepet tölt be a megfelelö környezet kialakitása, melyhez elengedhetetlen a terület ideális kiválasztása (Hunsinger \& Krotoski 2013). Ez azért létfontosságú, mert egy adott terület lekorlátozza az ott elhelyezhető eszközök számát illetve nagyságát.

Ahhoz, hogy a lehető legkevesebb hibát vétsük, a legkevesebbszer alkalmazzunk hibás, indokolatlanul nagy erőforrást igénylő eszközöket, ezzel pedig időt illetve 
energiát spóroljunk meg kézikönyvek közül is válogathatunk. Ezekben hasznos információkat találhatunk a virtuális térben történő oktatási-kutatási-tanítási módszerekről és azok alkalmazhatóságáról (Savin-Baden 2010). Az első lépésektől a gyakorlati alkalmazáson keresztül minden kérdésünkre választ kaphatunk. Azonban ahhoz, hogy igazán hatékony oktatássegítő módszerként alkalmazzuk a virtuális tér adta opciókat, az adott témában való elmélyülés és magas szaktudás kulcsfontosságú szerepet tölt be.

A szaktudást a virtuális térben lévő oktatásban alapvetően részt vevő oktató és a facilitátor vagy facilitátorok képviselik. Nélkülük nem valósulhat meg a virtuális térben történő oktatási folyamat. Szerepük nem csak az oktatói, de a hallgatói oldalról is monumentális szerepet tölt be. Nélkülözhetetlenek a virtuális térben föként a newbie korszakban, ahol olyan problémák elkerülését akadályozhatják meg csupán jelenlétükkel, melyek átlendítik a kezdeti nehézségeken a felhasználót (Schwarz 2002).

Newbie-nak nevezzük a Second Life világában első napjait töltő felhasználót. Általánosságban elmondható, hogy az avatár külsejének formázása és megfelelő önkép kialakítása az első teendő a regisztrációt követően (Ollé \& Kristóf 2014).

\section{Eszközök és módszerek}

Kijelenthető, hogy a felhasználók szempontjából esszenciális a newbie korszak akadálymentesítése. A kezdeti lelkesedést felerősíteni szükséges, melyhez elengedhetetlen az, hogy eleinte minden szükséges információt megkapjanak a leendő tanulók, akár többféleképpen is. A hallgatókat nem szabad általánosítani, nem mindenkinek ugyanolyan hatékony egy bizonyos módon átadott segítségnyújtás. Fontos a probléma több oldalról való megközelítése, valamint az is, hogy a hallgató bátran jelezze, ha valamit nem ért.

Gamage és munkatársai aszerint különböztették meg kutatásuk alanyait, hogy azok mennyire voltak tapasztaltak a virtuális terek használatában. Mindkét csoport egyetértett abban, hogy a platformok használata előnyt jelent a tanulás során, abban azonban eltért a véleményük, hogy mennyire valószínü az érzelmi kapcsolat a tanár és diák között ebben a sok felhasználót foglalkoztató világban. Mindkét csoport véleménye szerint a virtuális valóságok oktatási hasznosítása egyre szélesebb körben ajánlott, és főleg a félénk diákok számára nyilvánvalók ennek az előnyei (Gamage et al. 2011). Hammick és Lee vizsgálta is a félénkebb felhasználókat és úgy találták, hogy a fenti típusú személyek virtuális térben kevésbé találják magukat ijesztő helyzetekben, ellentétben a mindennapi kommunikációs helyzetekkel. Ugyanakkor, bár ezek a helyzetek jó hatással voltak a kommunikációs helyzetek megértésére, a kommunikációs képességükben így sem bíztak jobban. Megállapították, hogy bár a szégyenlösebb, félénkebb emberek szívesebben kommunikálnak így, maga a virtuális kommunikáció, ellentétben a valós, szemtől-szemben esetekkel, kevesebb meggyőző erővel bír (Hammick \& Lee 2014).

Lényegesnek tartjuk kiemelni, hogy a Second Life használata során problémákba is ütközhetünk. A nyilvános virtuális tereken nehezen kontrollálható egyes 
felhasználók viselkedése, az erőszak bizonyos formái a virtuális világban is lehetségesek (Aristeidou \& Spyropoulou 2015). A fentieken túl előfordulhatnak technikai problémák is, a nem megfelelő hardver, az internet hiánya. Egy török kísérlet során például a biztonsági okokból lekorlátozott internet okozott komoly problémát (Ata \& Orhan 2013).

Az esetlegesen előforduló problémákon túllépve azonban a Second Life Keelan és munkatársai által meghatározott előnyeit is fel kell vázolnunk. Tanulmányuk négy egyértelmú pozitívumot talált, ahol a hagyományos területekhez képest előnyöket nyújt a virtuális világok használata. A virtuális terek eltörölhetik a fizikai-földrajzi határokat azokban az esetekben, ahol messze esik egymástól a kutatás a fizikai világban és a gyógyítani, kezelni, vizsgálni kívánt embercsoport. A költségek csökkenthetők a különböző médiacsatornák keverésével, együttes felhasználásával. Az anonimitást felhasználva az avatarokon keresztül akár érzékenyebb, kényes témákban is lehetőség van beszélgetésre. A világ egymástól eltérő pontján élő embereket kapcsolhatunk össze (Keelan et al. 2015).

A Second Life keretrendszerébe történő regisztráció és a letöltés után kitárulhat előttünk egy világ, melyet teljes mértékben a virtuális tér lakói alakítanak. Nincsenek küldetések, célok, pontok, amiket össze kell gyüjteni az érvényesülés érdekében (Cheney \& Sanders 2011). A Second Life egy sor ugyanolyan jellemzővel rendelkezik, mint a számítógépes online játékok. Ilyenek az avatar megalkotása, interakciók a csoportokon belül, az avatar mozgatása, a virtuális világ megjelenése és jellemzői. A fejlesztések során át kell emelni azt a motiválást, amellyel a játékok az emberre hatnak, miközben a játékokhoz kötődő elvárásokat nem hozzuk magunkkal (Cheal 2009). A newbie korszak nagyon fontos, ha valaki könnyen átvészeli, örömmel tér vissza a virtuális térbe, azonban ha kellemetlen élményekkel gazdagodik ez időszakban, az akár a teljes elzárkózást is jelentheti. Többek között a könnyebb bevonódás megvalósulása okából vannak jelen a facilitátorok a virtuális térben.

\section{Elemzés}

Kutatásunkban a facilitátori tevékenységet felbontottuk, attól függően, hogy az oktatás milyen térben valósul meg. Négy különböző bár mégis, egymáshoz közel álló teret sikerült körvonalaznunk. (1.ábra) Ezeket a következőképpen neveztük el:

- valós tér,

- online megoldásokkal támogatott valós tér,

- online tér,

- virtuális tér. 


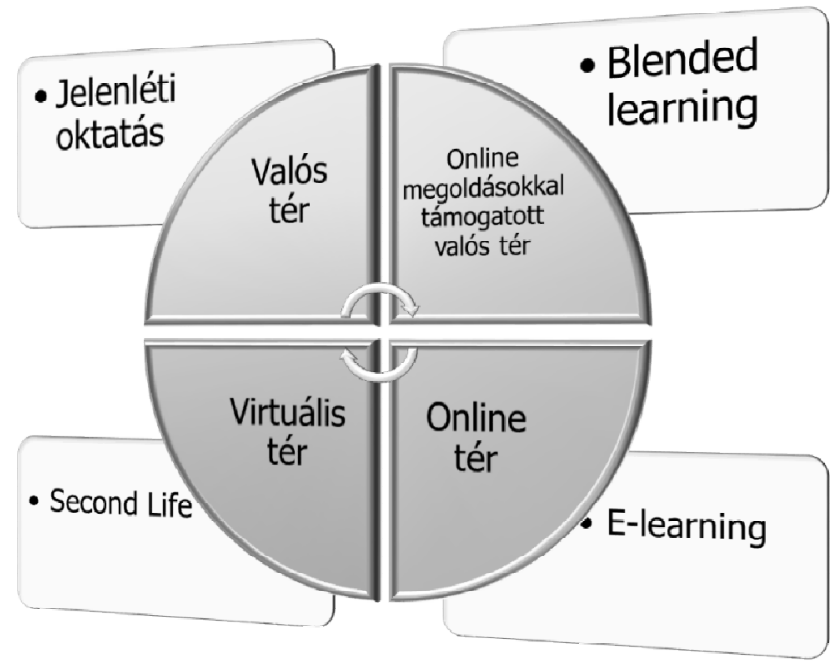

1. ábra: A facilitátori tevékenység terei.

\section{A valós tér}

A valós térben megvalósult történések leginkább a jelenléti oktatással jellemezhetők. Élőben, szemtől szemben folyik az oktatás, személyesen jelen van az oktató a hallgató és a facilitátor is egyazon helyszínen. A foglalkozást az oktató vezeti, mely elöre egyeztetett általa megszabott időpontban történik. A hallgatóság figyelemmel késéri az előadást, papírra jegyzetel, majd ebből készül fel a számonkérésre.

A valós térben történő tanítási-tanulási folyamatok lebonyolításánál segítő facilitátor szerepkörét három további feladatkörre bontottuk tovább, melyek a következők:

- megelözö, valós térbeli facilitátor,

- résztvevő, valós térbeli facilitátor,

- utólagos, valós térbeli facilitátor.

\section{Megelözö, valós térbeli facilitátor}

Összefoglalja az előadással (az oktatás egy részével) kapcsolatos tudományos cikkek, tanulmányok tartalmát és referálja azokat az előadónak az óra elött. Az anyagokat a könyvtárban keresi meg, elolvassa azokat, majd jegyzetet készít a legfontosabb információtartalommal. Gyakran kézzel ír és jegyzetel, a régi, klasszikus tanulásnak megfelelően. Ebből felkészül és szóban előadja az oktatónak a feljegyzéseit. Kézzel fogható segédanyagot készít papír alapon, melyet átad a hallgatóknak elősegítve ezzel a tananyag tisztán látását, megértését.

\section{Résztvevő, valós térbeli facilitátor}

Olyan személy, aki az oktató és hallgatóság mellett jelen van az órán. Miután a szükséges kutatásokat elvégezte, összegyüjti a témával kapcsolatos könyveket. Jegyzetet készít az általa összegyüjtött szakirodalomból, annotálja a legfontosabb információkat, majd egyeztet az oktatóval. Az előadás alatt a prezentációt magyarázó, általa készített segédeszközöket (táblázatokat, diagramokat, képeket) mutat be. A 
tanóra folyamán felmerülő problémákat, kérdéseket feljegyzi, a prezentáció helyes lefutását segíti.

Utólagos, valós térbeli facilitátor

Menedzseli az előadás anyagát. Bizalommal fordulnak felé a hallgatók az órával kapcsolatos kérdésekben. Válaszol és igyekszik megoldani a felmerülő problémákat. Ha nem az órák közben/után fogalmazódik meg a hallgatókban a kérdés, a fogadóórája időintervallumában személyesen megkereshetik. Az oktatóval a további feladatokkal kapcsolatban konzultál.

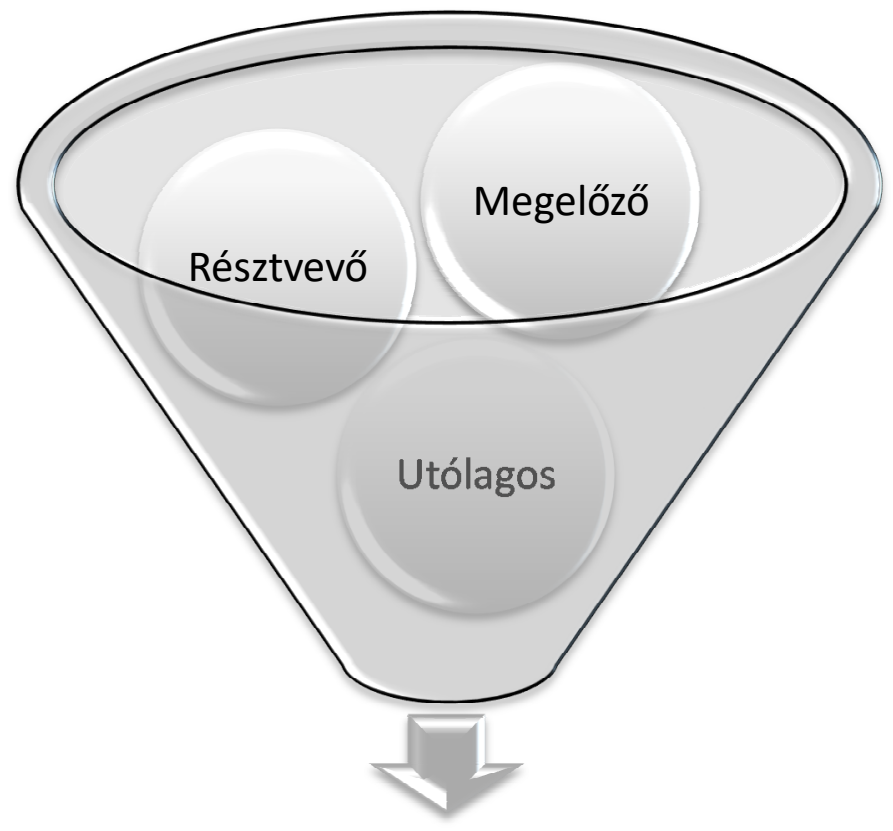

FACILITÁTORI SZEREP

2. ábra: A valós terek facilitátori szerepkörei.

\section{Az online megoldásokkal támogatott valós tér}

Az online megoldásokkal támogatott valós térben megvalósult oktatási-tanulási folyamatok a legtöbb felsőoktatási kar oktatásával jellemezhetők a legszemléletesebben. Az oktató tarthatja személyesen az előadást, de alkalmanként történhet többek között Youtube vagy Skype segítségével is a tananyag átadása, amennyiben az oktató nem tartózkodik munkájából kifolyólag az adott városban. A facilitátor személyesen jelen van minden órán. Az előadást az oktató vezeti, és annak időpontját, időintervallumát is ő határozza meg. A facilitátor online megoldásokkal növeli a teljesítményt. 
Mivel az online megoldásokkal támogatott valós tér is valós tér, így a korábban megismert három facilitátori szerepkört tudtuk meghatározni ebben az oktatási térben is.

\section{Megelözö, online megoldásokkal támogatott valós térbeli facilitátor}

Leginkább az internetet használja folyóiratok, tudományos cikkek elolvasására, letöltésére. Informatikai eszközön keresztül olvassa el és emeli ki a lényeget, melyet akár szóban akár interneten keresztül átad az oktatónak. Az oktatóval egyeztetve online megoldásokat is keres a tanóra témájával kapcsolatban. Otthonosan mozog az informatika és internet világában. Akár a Google tudós használatával, könnyen gyüjt anyagot a témával kapcsolatban. Előkészíti az órai előadáshoz szükséges segédanyagokat. Azzal együtt, hogy segíti a papíralapú segédanyagok elektronizálását, segíti az elektronikus segédanyagok kézzelfoghatóvá tételét is.

\section{Résztvevö, online megoldásokkal támogatott valós térbeli facilitátor}

Jelen van az órán, informatikai eszközök segítségével készít ábrákat, diagramokat. Az interneten keresztül képeket, videókat ment le, melyeket az előadás prezentálása közben magyarázatként szemléltet. Online megoldásokat keres segítség gyanánt, beépíti ezeket a segédanyagokba. Az infokommunikációs eszközök használatában technikai segítséget is nyújt.

Utólagos, online megoldásokkal támogatott valós térbeli facilitátor

Az előadás utáni kérdésekre online megoldásokat használva válaszol. Például emailben, közösségi oldal üzenetküldési felületén. Megosztja az interneten az anyagokat, kiküldi email-ben a változásokat, fontosabb információkat. A lehető legrövidebb időn belül válaszol. Mind az oktató, mind a tanulók felé biztosít online kommunikációs felületet.

\section{Az online tér}

A klasszikus értelemben vett e-learning a távoktatás online térben történik. Az elearning egy olyan keretrendszer, amely magába foglalja az előkészítést a tananyag átadást és az ellenőrzési tevékenységet is egyaránt, az oktató személyes jelenléte nélkül. Precízebb előkészületet igényel, mint a jelenléti oktatás vagy az online megoldásokkal támogatott valós térbeli tanítás. Azonban itt a hallgató nagyobb önállóságot gyakorolhat. Sokszor még időpont sincs meghatározva a tananyag elsajátításával kapcsolatban. Minden szükséges segédanyag, tananyag, kép, diagram, ábra a hallgató rendelkezésére áll a keretrendszeren belül. A tanuló gyakran szabad kezet kap a felhasználásra.

Az online térben történő facilitátori tevékenységet két további szerepkörre bontottuk, melyek a következők:

- megelőző, online térbeli facilitátor,

- folyamatos, online térbeli facilitátor. 


\title{
Megelözö, online térbeli facilitátor
}

Létrehozza az online tanulási környezetet. Hozzárendeli a felhasználókat, akikröl a listát az oktató bocsátja rendelkezésére. Jelszavas védelmet biztosít, hogy az adott kurzust, csak azon hallgatók tudják használni, akik rendelkeznek a jelszó ismeretével. Megosztja a felhasználókkal a szükséges jelszavakat, hogy használni tudják a keretrendszert. Az oktatóval történő egyeztetés után elhelyezi az internetes segédanyagokat.

\section{Folyamatos, online térbeli facilitátor}

Mivel online térben jóval kisebb a személyes kontaktus, a résztevő facilitátori szerepkör önmagában szükségtelenné válik, ahogyan az utólagos facilitátori szerep is. A kettő egybeolvadásából létrejön a folyamatos, online térbeli facilitátor. Öt értelmezhetjük úgy is, mint egy e-learning keretrendszer adminisztrátort néhány plusz tulajdonsággal. Figyeli és menedzseli a tanulók elörehaladását a tananyagban. A technikai feladatok mellett szakmai feladatokban is segítséget tud nyújtani, reagál az anyaggal kapcsolatos felmerülő kérdésekre.

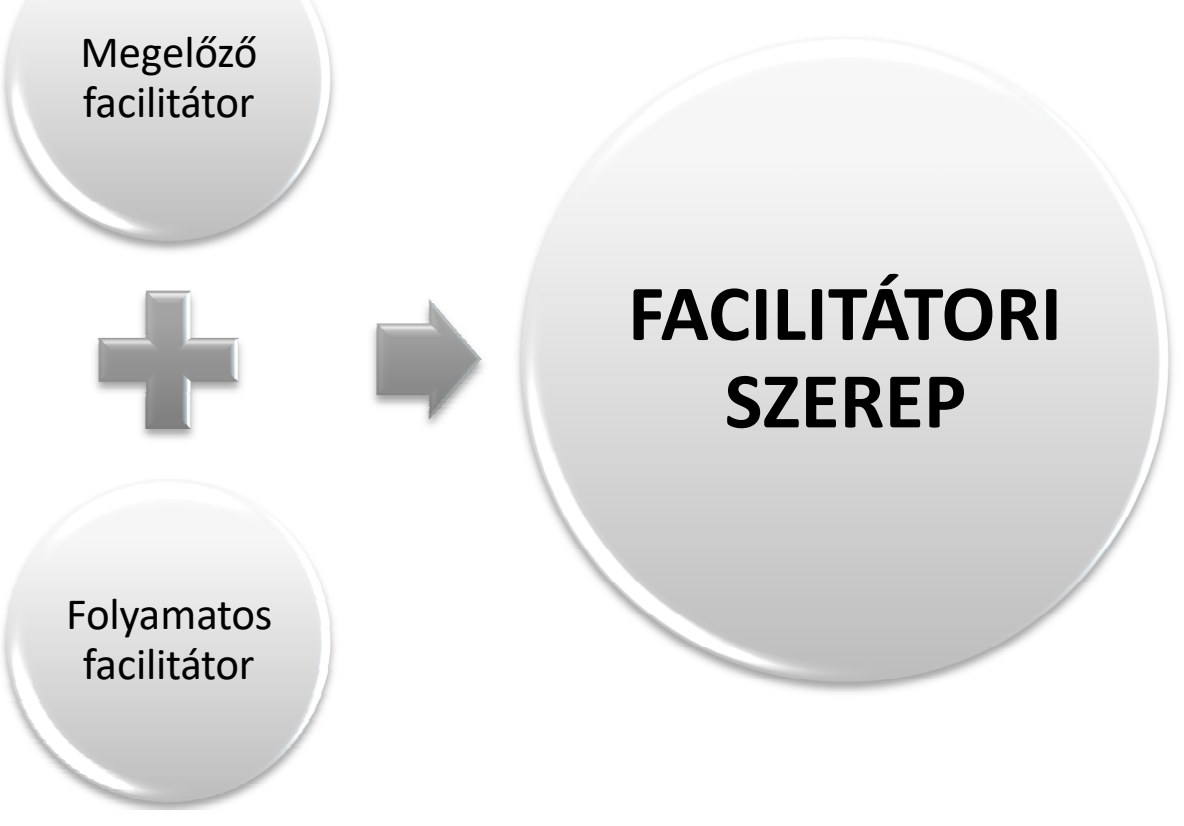

3. ábra: Facilitátori szerepek az online terekben.

\begin{abstract}
A virtuális tér
A virtuális térben történő tanítási-tanulási folyamatokat - elképzelhetö, hogy ennek a térnek oktatási helyzetekben meglévő újszerüsége, kiforratlansága miatt - tapasztalataink alapján nem kezelhettük egységesként, további két részre kellett bontanunk, melyek a következők:
\end{abstract}


- önálló tanulás virtuális tanulókörnyezetben,

- valós térbeli oktatás leképezése.

\section{Virtuális tér}
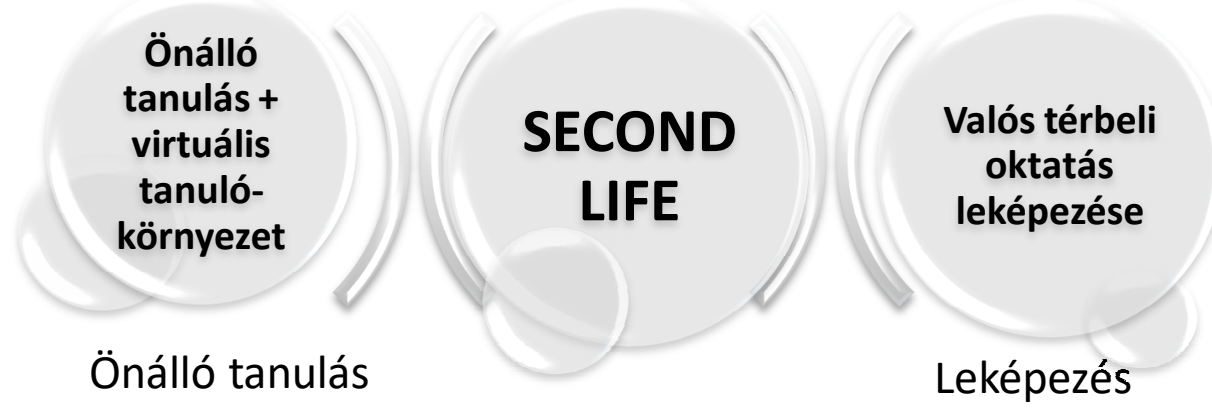

4.ábra: A virtuális térben előforduló két, jól megkülönböztethető oktatástípus.

Az önálló tanulás virtuális tanulókörnyezetben nem más, mint az online térben történő tanulás megvalósulása virtuális térben. Így az ilyen típusú tanítási-tanulási folyamatok esetén az online tereknél már körülhatárolt megelőző és folyamatos facilitátori szerepek jelennek meg.

A valós térbeli oktatás leképezése esetén természetesen a valós térben tapasztalt jellemzők valósulnak meg, ennek megfelelően, ebben az esetben a valós térben felbukkanó megelőző, résztvevő és utólagos facilitátorok szerepe kerül előtérbe.

A megelőző facilitátor mindkét esetben jelen van, és feladataik nem különülnek el érdemben egymástól. Ki kell tudnia alakítani a virtuális tanulási környezetet, annak menedzselésével együtt. A valós vagy online térben meglévő anyagokat leképezi a virtuális térbe úgy, hogy a felhasználók számára elérhető legyen. Ellenőrzi az eszközök müködését, ha hibákat észlel, megpróbálja kiküszöbölni azokat. URL címeket oszt meg a felhasználókkal, online adja át az első használat elötti alapvető információkat.

A virtuális tanulástámogató eszközökkel támogatott önálló tanulás során a másik facilitátori szerepkör a folyamatos facilitátor. Szerepe hasonló egy adminhoz, de a tananyaggal kapcsolatban is folyamatos rendelkezésre áll adott időintervallumban. Ellenőriznie kell a virtuális tanulástámogató eszközök müködését, egyes felmerülő hibákat saját maga is kiküszöbölhet. García-Peñalvo 2014-ben vizsgálta a virtuális térben történő önálló tanulási formát, ahol a tanulók a tanár jelenléte nélkül, csupán az általuk gyakoroltakra, az elért eredményeikre támaszkodnak. Azt találta, hogy ezek a nyitva hagyott lehetőségek fejleszthetik a tanulót, akár jobban is, mint a hagyományos tanítási módszerek. Így nemcsak jobb eredmények, hanem nagyobb elégedettség is elérhető (García-Peñalvo et al. 2014).

A valós térbeli oktatás leképezése során a megelőző facilitátor mellett jelen van a résztvevő és az utólagos facilitátor is. A résztvevő facilitátor az oktatási folyamatok során felbukkanó, virtuális tér okozta nehézségek áthidalásában segít. Nagyon fontos 
szerepe van új felhasználók esetén, ugyanis a newbie-k akár olyan alapvető nehézségekbe is ütközhetnek, mint a belépés. Feladatuk a kialakított tanulói környezet menedzselése, szükség esetén pozíciók megtalálása, lementése a térképen, hogy a jövőbeni visszatérés minél egyszerübb legyen a hallgatóság számára. A résztvevő facilitátor a hallgatók segítségére lehet a különböző grafikai beállításoknál, a képernyő felbontásának helyes kiválasztásánál. Az avatár mozgatásával kapcsolatos problémákra megoldást találhat, instrukciókkal láthatja el öket a különböző mozgástípusok célszerü használatával kapcsolatban. Az avatár külsejének megváltoztatásában és speciális egyéni igények alapján történő testre szabásában is a hallgatók rendelkezésére áll. A Second Life Marketplace, mint ruhatár és eszköz feltöltési opció használatának bemutatása és a virtuális térben megjelenő ruhák és eszközök használatbavételének ismertetése is a résztvevő facilitátor feladatkörébe tartozik. A hallgatók bármilyen oktatási és tanulási célon kívüli virtuális térrel kapcsolatos kérdéseikkel bátran és bizalommal fordulhatnak hozzá.

Az utólagos facilitátori szerep magába foglalja az elemzések, megfigyelések, értékelések készítését is. Az eredmények kiértékelése és a konzekvenciák levonása feladatkörök is a teendői között szerepelnek a hatékonyság javításának érdekében. Folyamatosan megfigyeli a hallgatókat, meghallgatja véleményüket és összegzi azokat. Válaszol a felmerülő kérdésekre, megoldást keres a problémákra, ha nem tudja egyből megválaszolni azokat. Időpont egyeztetési lehetőséget kínál, szem előtt tartja a határidős teendőket. Célja a résztvevő facilitátori szerepkör hatékonyságának további növelése.

\section{Jelentőségek}

A facilitátori tevékenységek létfontosságú szerepet töltenek be a virtuális térben, úgy gondoljuk, facilitátor nélkül képtelenség hatékony oktatási folyamatot megvalósítani. A kezdeti nehézségek áthidalása mellett a facilitátorok a használat közben fellépő esetleges kérdésekre és problémákra is megoldást nyújtanak. Oktatási szempontból megkülönböztettünk valós teret, valós teret online támogatással kiegészítve, online teret és virtuális teret. A facilitátor tevékenységét tekintve ezek a terek különbözőek, de egymáshoz mégis nagyon közel állnak. Megkülönböztettünk megelőző, résztvevő, utólagos és folyamatos facilitátori szerepet. Ezeket pontosan meghatároztuk, példákkal szemléletesebbé és kézzelfoghatóbbá tettük. Meggyőződésünk, hogy a felsőoktatás területén - legyen ez Magyarországon vagy bárhol a világban - több olyan témakör is létezik, melyek esetében érdemes lenne facilitátorokat alkalmazni, az oktatói és hallgatói lét megkönnyítése és hatékonyabbá tétele végett.

\section{Következtetések}

A Second Life virtuális világát használják a világ legtöbb táján oktatáskutatási projektek megvalósítására. Ennek oka lehet az interaktívan változó környezet, a részt- 
vevők viszonylagosan magas száma, valamint az is, hogy az egyes alapvető tárgyak, eszközök kialakítása, létrehozása, beszerzése aránylag egyszerünek tekinthető. Jelen korunk hallgatói társadalma igényli a jelenléti oktatást kiegészítő módszerek alkalmazását. A XXI. században már nem meglepő, hogy az oktatók minden lehetőséget figyelembe véve igyekeznek tartani a tempót az Y és $\mathrm{Z}$ generációs hallgatókkal. Ugyanis a tudásanyaggal párhuzamosan az információkhoz való hozzáférés is gyors tempóban változik. Kihasználva az információs és kommunikációs technológiákat (IKT), olyan új módszerekkel találkozhatunk, amelyek jelentősen hozzájárulnak a hallgatók figyelemfelkeltéséhez és motivációjuk emeléséhez egyaránt. Nem meglepő tehát, hogy a háromdimenziós virtuális környezetek is szolgálnak már oktatási célokat, melyek szenzációs kiegészítői a tradicionális oktatási módszereknek.

A Second Life virtuális tere olyan oktatási környezet kialakításához biztosít teret, ahol a hallgatók tudásszomját kielégítve számos képességük fejleszthető, melynek a későbbiekben hasznát vehetik a valós életben is. Fejlődik az egyéni és csoportos munka, könnyebben elsajátítható emellett a szükségszerü tudás. Bizonyos esetekben makulátlan kiegészítő lehet a tananyag elsajátításában. Esszenciális azonban, hogy a virtuális környezetben történő alkotáskor a készítő személy, aki specialista ebben, rendkívül precíz módon készítse el a tárgyakat. Az alábbi kritérium teljesülése esetében, a virtuális térben olyan nehéz, veszélyes, és lehetetlen dolgokat tudunk felülmúlni, melyeknek csak kreativitásunk szabhat határt.

Tapasztalataink alapján a virtuális térben történő első lépések negatív attitüdöket is ébreszthetnek a hallgatókban. Amelyek szorongást, nyomasztó érzéseket is kiválthatnak, valamit ahhoz is vezethetnek, hogy elforduljanak ettől a lehetőségtől. A digitális írástudás szintje egyre magasabb, így eleinte bizakodva lépnek be a virtuális környezetbe. Azonban sokszor az új környezet és kezdeti nehézségek átlépéséhez nem elegendőek a formális ismeretterjesztések és guide-ok. Ahhoz, hogy megkönynyítsük az első lépést, facilitátorokat alkalmazunk. Ehhez elengedhetetlen volt a facilitátorok szerepkörének meghatározása, akik másfelől nyújtanak megoldást a felmerülő problémákra. A megelőző, résztvevő, utólagos és folyamatos facilitátori szerepkörök betöltéséhez speciális képességek ismerete szükséges. Reméljük tanulmányunk felhívja a figyelmet a facilitátori szerep fontosságára, akár virtuális térben történő, akár valós térben történő oktatási folyamatról is legyen szó.

\section{Hivatkozások}

1. Aristeidou, M., \& Spyropoulou, N. (2015). Building Technology and Science Experiences in 3D Virtual World. Procedia Computer Science, 65, 259-268.

2. Ata, R., \& Orhan, S. (2013). An Implementation of Virtual Worlds Platform for Educators in Second Life. Procedia-Social and Behavioral Sciences, 83, 1027-1031.

3. Bauman, E. B. (2012). Game-based teaching and simulation in nursing and health care. Springer Publishing Company. 
4. Božović, M., Milošević, D., Blagojević, M., \& Mitrović, A. (2014). Applying sloodle virtual environment for medical course preparation. In 5th International conference E-learning, Belgrade (pp. 126-131).

5. Cheal, C. (2009). Student perceptions of a course taught in Second Life. Innovate: Journal of Online Education, 5(5), 2.

6. Cheney, A., \& Sanders, R. L. (2011). Teaching and learning in 3D immersive worlds: Pedagogical models and constructivist approaches. Hershey, PA: Information Science Reference.

7. Cristofari, C., \& Guitton, M. J. (2014). Mapping virtual communities by their visual productions: The example of the Second Life Steampunk community. Computers in Human Behavior, 41, 374-383.

8. de Melo, F. R., Flôres, E. L., de Carvalho, S. D., de Teixeira, R. A. G., Loja, L. F. B., \& de Sousa Gomide, R. (2014). Computational organization of didactic contents for personalized virtual learning environments. Computers \& Education, 79, 126-137.

9. de Noyelles, A., \& Seo, K. K. J. (2012). Inspiring equal contribution and opportunity in a 3D multi-user virtual environment: Bringing together men gamers and women non-gamers in Second Life. Computers \& Education, 58(1), 21-29.

10. Gamage, V., Tretiakov, A., \& Crump, B. (2011). Teacher perceptions of learning affordances of multi-user virtual environments. Computers \& Education, 57(4), 2406-2413.

11. García-Peñalvo, F. J., Cruz-Benito, J., Maderuelo, C., Pérez-Blanco, J. S., \& Martín-Suárez, A. (2014). Usalpharma: A cloud-based architecture to support Quality Assurance training processes in health area using Virtual Worlds. The Scientific World Journal, 2014.

12. Guitton, M. J. (2012). Living in the hutt space: Immersive process in the star wars role-play community of second life. Computers in Human Behavior, 28(5), 1681-1691.

13. Guitton, M. J. (2015). Swimming with mermaids: communication and social density in the Second Life merfolk community. Computers in Human Behavior, 48, 226-235.

14. Hammick, J. K., \& Lee, M. J. (2014). Do shy people feel less communication apprehension online? The effects of virtual reality on the relationship between personality characteristics and communication outcomes. Computers in Human Behavior, 33, 302-310.

15. Horváth, Gy. (2004). Pedagógiai pszichológia. Nemzeti Tankönyvkiadó: Budapest.

16. Hunsinger, J., \& Krotoski, A. (2013). Learning and research in virtual worlds. Routledge.

17. Keelan, J., Ashley, L. B., Morra, D., Busch, V., Atkinson, K., \& Wilson, K. (2015). Using virtual worlds to conduct health-related research: Lessons from two pilot studies in Second Life. Health Policy and Technology, 4(3), 232-240.

18. Lewin, K., Lippitt, R., \& White, R. K. (1939). Patterns of aggressive behavior in experimentally created ,social climates." Journal of Social Psychology, 10, 271-299. 
19. Novotny, J. M., \& Griffin, M. T. Q. (2011). A Nuts and Bolts Approach to Teaching Nursing. Springer Publishing Company.

20. Ollé, J., \& Kristóf, Z. (2014). Learning, teaching and developing in virtual education. ELTE. Eötvös University Press: Budapest.

21. Punjabi, S. (2015). Child Development \& Pedagogy for CTET \& STET. Disha Publication.

22. Savin-Baden, M. (2010). A practical guide to using Second Life in higher education. McGraw-Hill Education (UK).

23. Schwarz, R. (2002). The skilled facilitator new \& revised: a comprehensive resource for consultants, facilitators, managers, trainers, and coaches. San Franciso: Jossey-Bass Publishers.

24. Schwarz, R., Davidson, A., Carlson, P., \& McKinney, S. (2011). The skilled facilitator fieldbook: Tips, tools, and tested methods for consultants, facilitators, managers, trainers, and coaches. John Wiley \& Sons.

25. Sullivan, D. K., Goetz, J. R., Gibson, C. A., Mayo, M. S., Washburn, R. A., Lee, Y., et al. (2016). A virtual reality intervention (Second Life) to improve weight maintenance: Rationale and design for an 18-month randomized trial. Contemporary Clinical Trials, 46, 77-84.

26. Thackray, L., Good, J., \& Howland, K. (2008). Difficult, Dangerous, Impossible...: Crossing the boundaries into Immersive Virtual Worlds. In Learning in Virtual Environments International Conference (p. 324). 